\title{
Effects of el nino on distribution of chlorophyll- $a$ and sea surface temperature in northen to southern sunda strait
}

\author{
Mukti Trenggono ${ }^{1 *}$, Amron Amron ${ }^{1}$,Wanda Avia Pasha ${ }^{1}$ and Damar Lazuardy Rolian ${ }^{1}$ \\ 1 Fisheris and Marine Science Faculty, Jenderal Soedirman University, Kampus Unsoed \\ Karangwangkal, Purwokerto 53122 Indonesia
}

\begin{abstract}
Sunda Strait is an important passage for the Java Sea water to flow into the Indian Ocean. There is Java sea in North close to Karimata Strait and Eastern Indian Ocean in South part. Headed from north to south of Sunda Strait, has a high primary productivity that signifies the fertility of water. The strong EI Nino (SOI) in 2015, hypothesized to affect variability values of a-chlorophyll content and sea surface temperature in this area. The research aims to know the distribution pattern of chlorophyll-a, and sea surface temperature due to El Nino effect on transition season I (March, April and May 2015). The relationship of both with SOI was analyzed by simple linear correlation analysis. The results showed that the distribution of chlorophyll-a in Northen Sunda Strait is not affected by EI Nino but comes from the mouth of the Musi River. The pattern of sea surface temperature distribution from Northern to Southern of Sunda Strait showed in this area affected by El Nino so that the temperature is cooler. The relationship of chlorophyll-a with SOI has a negative moderate correlation (-0.532), indicating that chlorophylla in this waters have the direction opposite to SOI and sea surface temperature with SOI has a strong positive correlation (of 0.959 ).
\end{abstract}

\section{Introduction}

The Sunda Strait is located between the islands of Indonesia are among the territorial waters of the island of Sumatra and Java, shown in Figure 1. Astronomical position in the Sunda Strait is located at coordinate 2-5 ${ }^{\circ}$ South latitude and 107-104 ${ }^{\circ}$ East longitude [1]. The water body of the Sunda Strait is one of the areas that was essential in the activity of fishing. The dynamic water body conditions of the Sunda Strait influenced by the flow from the Java Sea and the Indian Ocean so that the mixing of the two water masses affect ${ }^{1}$ the abundance and productivity of pelagic fisheries in the region. Most of the mass of the water heading to the Indian Ocean through the Sunda Strait.

* Corresponding author: mukti.trenggono79@gmail.com 
Information on variability spatial temperature and chlorophyll-a sea level can be used to simplify the management and utilization of fishery resources as the basis for the suspect and determine the waters the potential for fishing ground. Sea surface temperature (SST) is the water temperature close to the surface of the sea. The water temperature of the sea mainly in the surface layer is heavily dependent on the amount of light receives from the Sun. The areas that receive the most sunlight is an area that is located at a latitude of $0^{\circ}$ , therefore, the temperature of the sea water is highest at the equator [2]. Seawater surface temperature usually ranges from $27{ }^{\circ} \mathrm{C}-29{ }^{\circ} \mathrm{C}$ in the tropics and $15{ }^{\circ} \mathrm{C}-20{ }^{\circ} \mathrm{C}$ in subtropical areas. This temperature is decreasing regularly according to depth. The seawater temperature is relatively constant between $2^{\circ} \mathrm{C}-4^{\circ} \mathrm{C}$ at a depth of more than $1000 \mathrm{~m}$ [3]. Sea surface temperature forms a zone based on the latitude. Getting closer to the Equator (low latitude) the temperature will increase in contrast to high latitude, the temperature decreased.

The crucial part is the nutrient for the growth of phytoplankton in the sea as well as the distribution of nutrients can be caused by the existence of a tropical storm on the surface, the upwelling and downwelling transfer [4]. The concentration of chlorophyll-a in waters of the beach and coastline are higher due to due to supply nutrient supply through run-off of the River from the Mainland, whereas low concentrations of chlorophyll-a in waters off the coast because of the lack of supply of nutrients from the mainland directly [5]. However, in some places still found the concentration of chlorophyll-a high enough, though far from the Mainland. The situation caused by the presence of upwelling. Upwelling or water mass ascent is the process of the accession of the mass of water from the deeper layers to the layer above or head to the surface [6].

Climate variability and change on the coast and the sea can have an impact on the uncertainty of the time and location of the occurrence of a potential fishery catch. Seasonal and annual climate variability in Indonesia is affected by the monsoon and ENSO [7]. Monsoon climate affects Indonesia through the movement of a point after the culmination of the Sun which resulted in Indonesia experienced a rainy season and a dry season [8].

The main factors that also affect the variability of climate in Indonesia are the ENSO (El Nino Southern Oscillation). ENSO is atmospheric sea interaction are centered in the region of Equatorial Pacific Ocean [8] (Aldrian, 2008) which cause global climate anomalies [9]. Give ENSO effect on the symptoms of the condition of the sea in Indonesia that is becoming cooler in warmer El Nino and La Nina year [8]. ENSO consists of three normal events, namely the phenomenon of El Nino and La Nina. Division criteria on each depending on the Southern Oscillation Index (SOI) from April (0) to March (+1). The aims of this study are to determine the distribution pattern of chlorophyll-a, and sea surface temperature due to El Nino effect on transition season I (March, April and May 2015).

\section{Material And Method}

\subsection{Satellite Data}

Sea Surface Temperature Data and Chlorophyll- $a$ were downloaded from https://oceancolor.gsfc.nasa.gov with spatial focus $4 \mathrm{~km}$ using Aqua Modis level 3 monthly and Chlorophyll- $a$ data using OCI algorithm. Aqua/Terra Satellite has 36 bands and the satellite can orbit in entire earth every $1-2$ days, Aqua tracks over the South to North and Terra tracks over North and South [10].

\subsection{Methods}


The method used is the assimilation of the modeling result by using the Ocean Data View 4 software for spatial variability which analyzed by descriptive and statistic using correlation to find out the influence of ENSO on the Sea Surface Temperatures against different parts of the North and the South of Sunda Strait using Minitab statistical software 16. SPL data and chlorophyll-a were gained using MODIS image recording in March, April, and May of the year 2015. The image data processed using the Ocean Data View 4 and SeaDas 7.4. The coordinates point when cropping the image were from $2^{\circ}$ North; $100^{\circ}$ West; $8^{0}$ South; $110^{\circ}$ East.

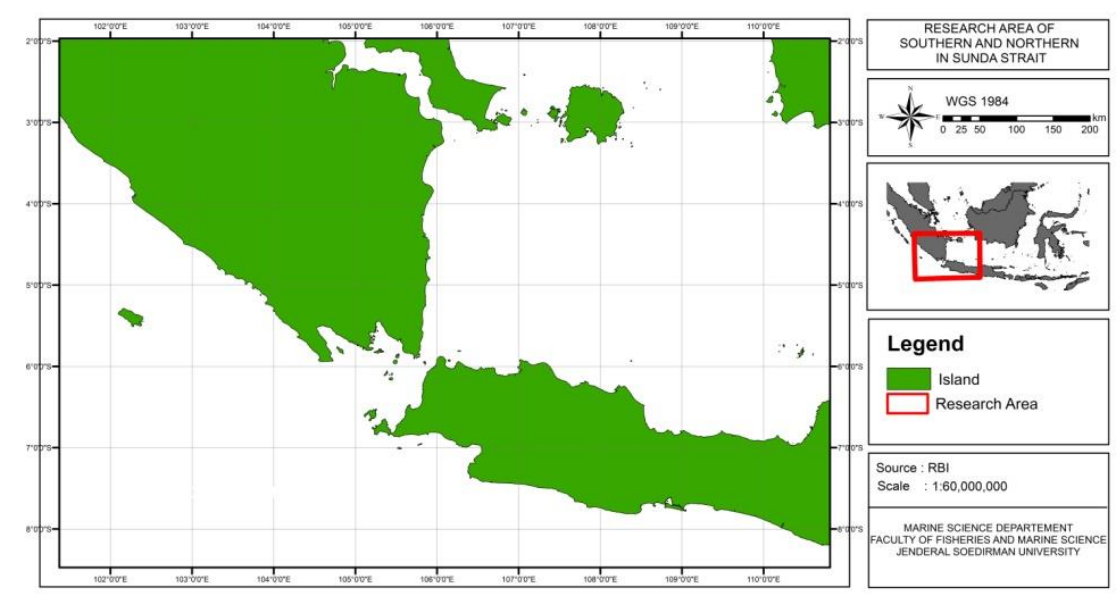

Fig. 1. Location of Research.

\section{Result and Discussion}

\subsection{Distribution of Sea Surface Temperature}




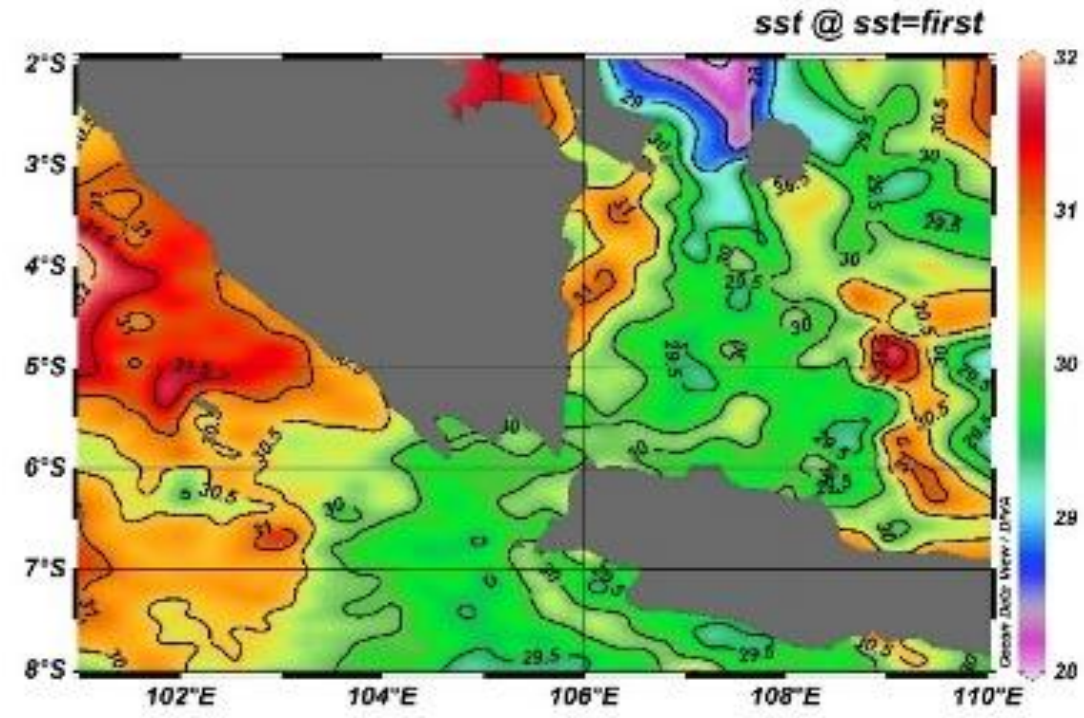

(a)

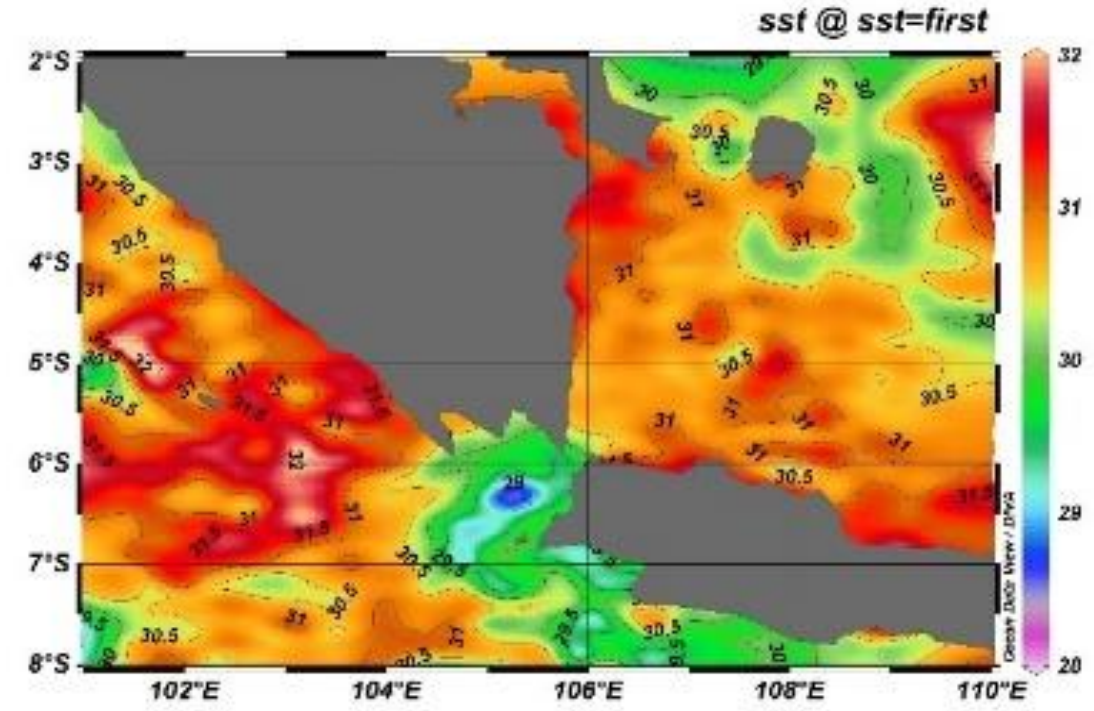

(b) 


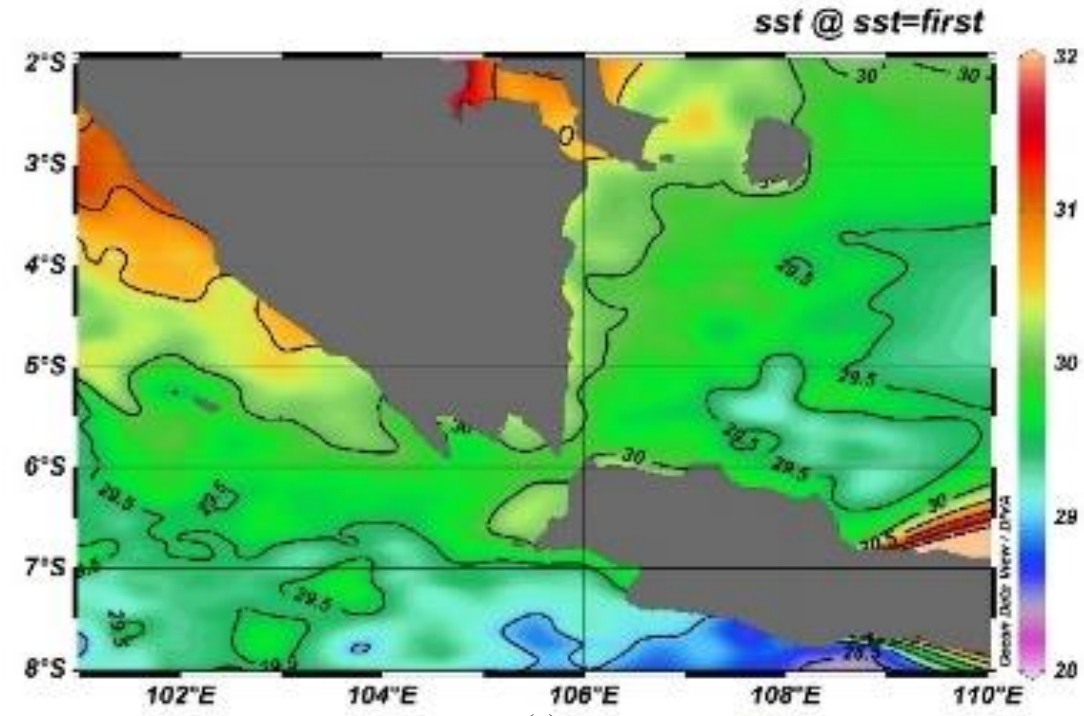

(c)

Fig. 2. Spatial distribution of Sea Surface Temperature 2015 in the Sunda Strait (a) March, (b) April, (c) May.

The results of the analysis show the temperature in March, April and May 2015 through the image (2a-c) has been changed. Surface temperature in March (Figure 2.a) shows the presence of mixing temperature on the northern part of the Sunda Strait ranges from 29.5$31.5^{\circ} \mathrm{C}$ in territorial waters near the Karimata Strait. The sea surface temperature on Sunda Strait which located between Java and Sumatra island have same tend to be stable until Hindia Ocean valued $30^{\circ} \mathrm{C}$ (Figure 2.a). On April 2015 (Figure 2.b) the waters of the southern part of tend to increase from March 2015, the magnitude of temperature in South of Sumatra sea range between $30^{\circ} \mathrm{C}-31.5^{\circ} \mathrm{C}$, in general, the water's temperature is normal. In Figure 2.c May 2015 showed a lower temperature difference i.e. amounting to $29.5{ }^{\circ} \mathrm{C}$ in both parts the waters spread out equally were the North and the South is relatively the same. 


\subsection{Distribution of Chlorophyll- a}

\section{chlor_a@chlor_a=first}

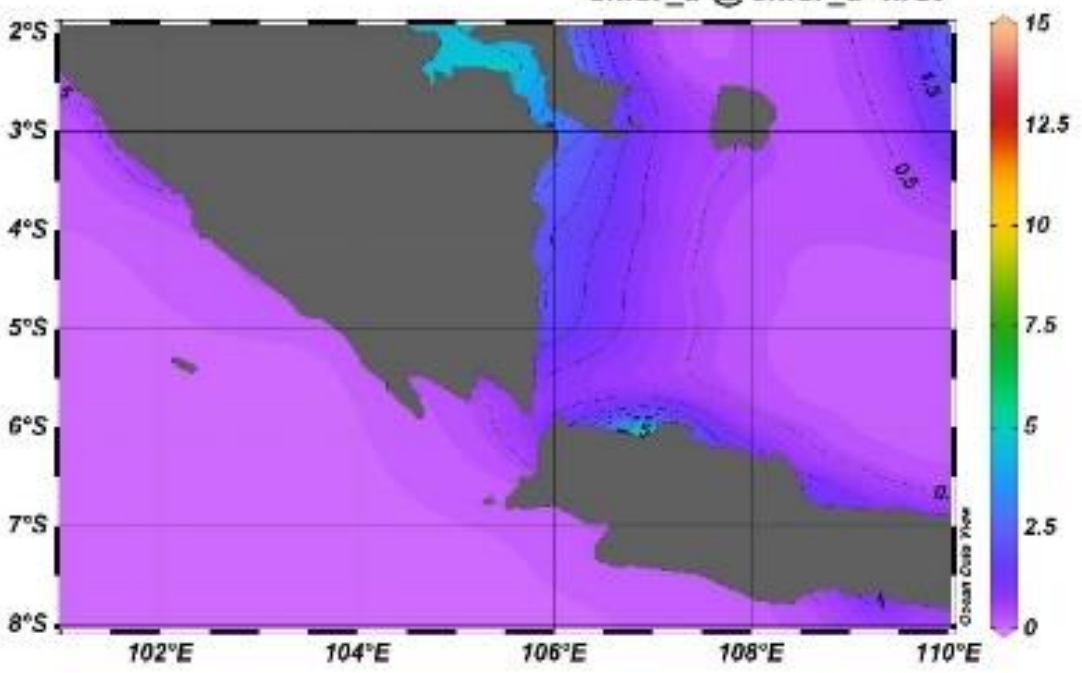

(a)

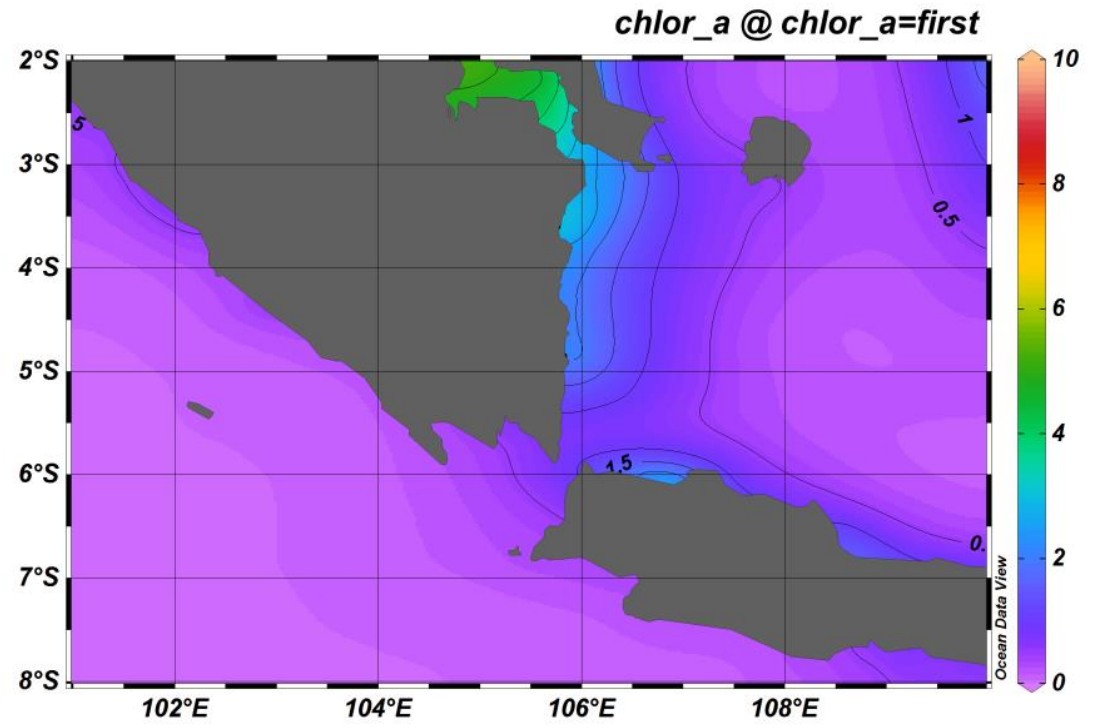

(b) 


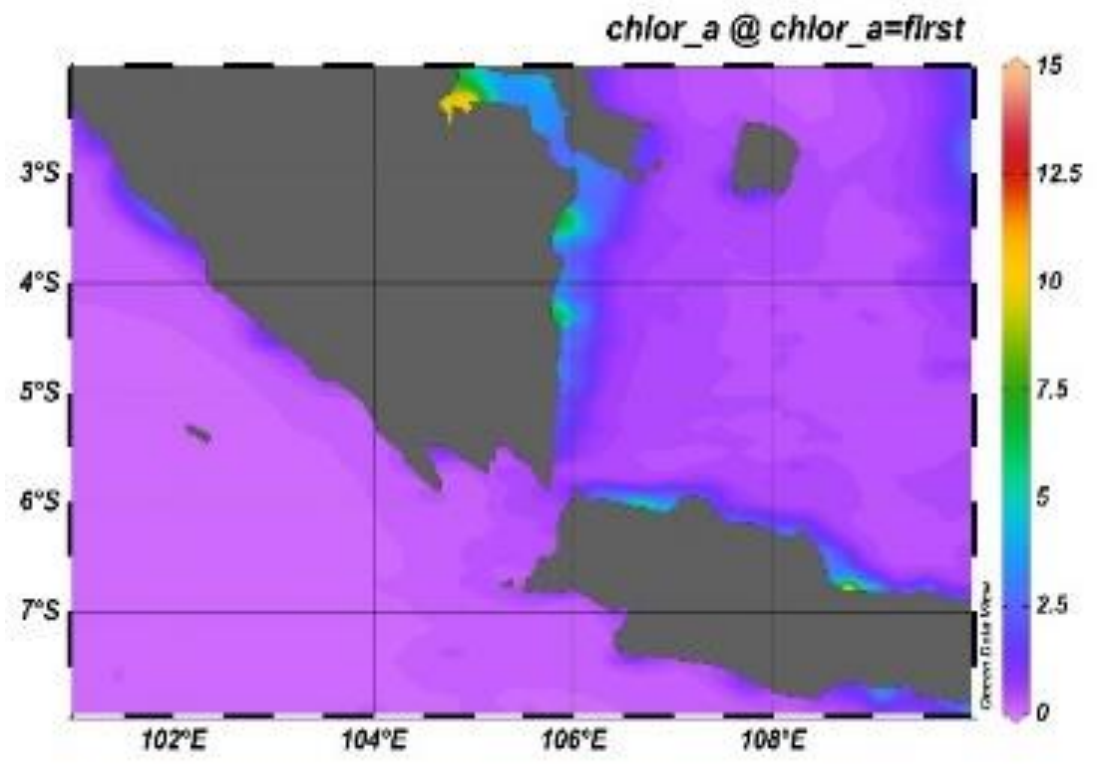

(c)

Fig.3. Spatial distribution of chlorophyll-a in 2015 the Sunda Strait (a) March, (b) April, (c) May

In Figure 3.a looks that chlorophyll in March in the northern part of the Sunda Strait has chlorophyll range $1.5-5 \mathrm{mg} / \mathrm{m}^{3}$ and the southern part of the Sunda Strait has the value ranges of chlorophyll $0-1.5 \mathrm{mg} / \mathrm{m}^{3}$. In Figure 3.b looks that chlorophyll in April in the northern part of the Sunda Strait has chlorophyll range 1-6 mg/m $\mathrm{m}^{3}$ and the Southern part of the Sunda Strait has the value ranges of chlorophyll $0-1.5 \mathrm{mg} / \mathrm{m}^{3}$. In Figure 3.c look that chlorophyll in May has increased from the previous month, in the northern part of the Sunda Strait has chlorophyll range $1.5-9 \mathrm{mg} / \mathrm{m}^{3}$ and the southern part of the Sunda Strait has the value ranges of chlorophyll $0-1.5 \mathrm{mg} / \mathrm{m}^{3}$.

\subsection{The Correlation Between Sea Surface Temperature With SOI}

Table 1. Pearson correlation Sea Surface Temperature between with SOI.

\begin{tabular}{lc}
\hline Pearson correlation of SST and & 0.959 \\
SOI & \\
P-Value & 0.183 \\
\hline
\end{tabular}

Based on the coefficient of the correlation between sea surface temperatures with SOI years 2015 of 0.959 positive relationships with directions as well as the level of the relationship is very strong. The value of the p-value of the year 2011 of 0.183 which is greater than 0.05 , so it can be said that there is no significant correlation in 2015 between sea surface temperatures with the SOI. The correlation between sea surface temperature by SOI in the year 2015 indicates the direction of the relationship is positive, so the temperature of the sea surface with the SOI has value and the same direction. Sea surface temperature and SOI in the year 2015 decline. 


\subsection{The Correlation Chlorophyll- a With SOI}

Table 2. Pearson correlation Chlorophyll-a between with SOI.

\begin{tabular}{lc}
\hline $\begin{array}{l}\text { Pearson correlation of CHL-A } \\
\text { and SOI }\end{array}$ & -0.532 \\
P-Value & 0.643 \\
\hline
\end{tabular}

Based on the coefficient of correlation between Chlorophyll- $a$ with SOI year 2015 of 0.532 negative relationships with directions as well as the level of strong relationships. The value of the p-value of the year 2011 of 0.643 which is greater than 0.05 , so it can be said that there is no significant correlation in the year 2015 with Chlorophyll- $a$ between SOI. Correlation with Chlorophyll- $a$ SOI in the year 2015 indicates the direction of the relationship is negative, so the Chlorophyll- $a$ with SOI has value and opposite direction. If the value of the Chlorophyll- $a$ is an increase, then the value of the SOI will go down. If the value of the Chlorophyll- $a$ has decreased, then the value of the SOI will rise.

On the territory of the western part of Sumatra occurred high differences in temperature with the southern part near the island of Java. The high temperature in the western part of Sumatra occurred due to the influence of the monsoon. There is a relationship between the variability of monsoon and sea surface temperature [11]. Both North and South area of Sunda Straits to Karimata straits were the warmest month phenomenon and a lower temperature difference indicating the presence of upwelling [10]. The highest temperature areas exist in the territorial waters of Karimata Strait with temperature $30^{\circ} \mathrm{C}$ state occurs due to the input of warm water from the river which modified before gets the mass output from the ITF (Indonesian Throughflow) [12].

Spatial distribution of chlorophyll in March, April and may seem that chlorophyll concentration values in the northern part of the Sunda Strait relative high in this case because the coastal areas located around the estuary of the Musi River, which resulted in a sufficient intake of nutrient substances the height of land. It is also reinforced by [13] the spread of chlorophyll-a concentration, in general, is relatively lower in the central part of the waters and the ever increasing towards the coastal waters. Movement of water masses to the East is causing the vacancy and will be replaced by water masses from a lower layer which contain cooler nutrient-rich. According to [14], stating that the concentration of chlorophyll-a can be caused by a high occurrence of nutrient-enriched on the surface layer of the waters through the various processes of the dynamics of water masses, including upwelling, vertical mixing of water masses and the mass movement of water.

Spatial distribution of chlorophyll on March, April and may seem that chlorophyll concentration value in the South of Sunda Strait relative low. This was a result of low water masses input in South of Sunda Strait which contains high nutrients from the coastal. On the Southwestern part of Java, the concentration of chlorophyll-a height that occurred in the East and the transition Seasons II is caused by the occurrence of upwelling along the southern coast of Java, at a time when Southeast Monsoon [15]. 


\section{CONCLUSION}

The pattern of sea surface temperature distribution from Northern to Southern of Sunda Strait showed in this area affected by El Nino so that the temperature is cooler. The results showed that the distribution of chlorophyll-a in Northen Sunda Strait is not affected by El Nino but comes from the mouth of the Musi River. The relationship between chlorophyll-a with SOI has a negative moderate correlation (-0.532), indicating that chlorophyll-a in this waters have the direction opposite to SOI in contrast to the relationship between sea surface temperature with SOI which has a strong positive correlation (of 0.959). 


\section{Reference}

1. J.T. Potemra, P.W. Hacker, O. Melnichenko, and N. Maximenko. J. G. Satellite estimate of freshwater exchange between the Indonesian Seas and the Indian Ocean via the Sunda Strait, 121, 5098-5111 (2016).

2. P.K. Weyl. Oceanography. An Introduction to The Marine Environment. John Wiley \& Sons Inc. New York (1970).

3. C.A.M. King. Introduction to Coastal Oceanography. McGrow Hill. New York (1963).

4. Zhao, Hui. and Ling Tang. J. G. Effect of 1998 El Nino on the distribution of phytoplankton. 112 (2007)

5. Nybakken, J.W. Biologi Laut: Suatu Pendekatan Ekologis. Gramedia. Jakarta (1992)

6. H. V. Sverdrup, M. Johnson and R. H. Fleming. The Oceans, Their Physics, Chemistry and General Biology. Prentice-Hall Inc. New York, NY (1942)

7. Z. Sitompul and E. Nurjani. J.B.I. Pengaruh El Nino Southern Oscillation (ENSO) terhadap Curah Hujan Musiman dan Tahunan di Indonesia. 2, 1 (2013).

8. E. Aldrian, Meteorologi Laut Indonesia. Jakarta : Badan Meteorologi dan Geofisika (2008).

9. K. E, Trenberth, and J. M. Caron. J. C. The Southern Oscillation Revisited: Sea Level Pressures, Surface Temperatures and Precipitation. 13, 4358 - 4365 (2000).

10. D W. Kusuma Murdinanto, A. Aden, L Y. Sukresno B, Jatisworo D. Hanintyo R. IOP Conference Series: Earth and Environmental Science 98 (2017)

11. Z . Kunarso, M. Ario, M. Raden, P. Bayu, Harmon. IOP conf. Series: Earth and Environmental Science. Impact of Monsoon to Aquatic Productivity and Fish Landing at Pesarawan Regency waters. 116 (2017).

12. R. Susanto, D. Zexun, Wei, R. T. Adi, Fan Bin, Li Suhijang, Fang Guohong. Acta Oceanol. Sin. Observations of the Karimata Strait througflow from December 2007 to November 2008. 32, 1-6 (2013).

13. B. Nababan, K. Simamora. J.I.T.K.T. Variability Of Chlorophyll-A Concentration And Sea Surface Temperature Of Natuna Waters. 4 (2012).

14. D. J, Pugesehan. J. Agroforestri. Analisis Klorofil-A Fitoplankton (Produktivitas Primer) di Perairan Pantai Netsepa Kabupaten Maluku Tengah. Politeknik Perdamaian Halmahera. Tobelo. 4, 272- 278 (2010). 
15. R. D. Susanto, A. L. Gordon, Q. Zheng. Upwelling along the coasts of Java and Sumatra and its Relation to ENSO. Geophysical Research Letters, 28, 1599-1602 (2001). 